\title{
References
}

Barraclough, D. R. \& Malin, S. R. C. 1971: Synthesis of international geomagnetic reference field values. Rep. Inst. geol. Sci. 71, 1, 26 pp.

Barraclough, D. R., Harwood, J. M., Leaton, B. R. \& Malin, S. R. C. 1975: A model of the geomagnetic field at epoch 1975. Geophys. J. Roy. Astron. Soc. 43, 645-660.

Bhattacharyya, B. K. 1969: Bicubic spline interpolation as a method for treatment of potential field data. Geophysics 34, 402-423.

Green, A. G. 1972: Magnetic profile analysis. Geophys. J. Roy. Astron. Soc. 30, 393-403.

Henderson, R. G. 1960: A comprehensive system of automatic computation in magnetic and gravity interpretation. Geophysics 25, 569-585.

Kofoed, E. \& Larsen, I. A. 1976: Brugervejledning. RECKU Publ. No. 1, 70 pp. Copenhagen.

Larsen, H. C. 1975: Aeromagnetic investigations in East Greenland. Rapp. Grønlands geol. Unders. 75, 88-91.

Nabighian, M. N. 1972: The analytic signal of two-dimensional magnetic bodies with polygonal cross-section: its properties and use for automated anomaly interpretation. Geophysics 37, 507-517.

Nabighian, M. N. 1974: Additional comments on the analytic signal of two-dimensional bodies with polygonal crosssection. Geophysics 39, 85-92.

Rudman, A. J. \& Blakely, R. F. 1975: Fortran program for the upward and downward continuation and derivatives of potential fields. Occ. Pap. Ser. Indiana geol. Surv. 10, 23 pp.

Thorning, L. 1976: Aeromagnetic surveys in southern and central West Greenland between $63^{\circ}$ and $71^{\circ}$ N. Rapp. Grønlands geol. Unders. 80, 61-65.

\section{Investigations of Quaternary geology on the west coast of Disko, central West Greenland}

\section{Joakim Donner}

During summer 1976 the coasts of Nordfjord, Mellemfjord and Disko Fjord were investigated. All three fjords were outlets for large valley glaciers moving towards the outer western coast of Disko. Some of the till material transported by the glaciers came from the inner parts of the island, as seen for instance in Nordfjord, where the material contains gneiss from the outcrops some way up in Stordal, the valley NW of the head of Nordfjord. However, the drift in the fjords consists mostly of the local basalt. During the retreat of the glaciers lateral moraines and kame terraces were deposited on the slopes. In Nordfjord they are at about 100 $m$ above sea level and at about the same altitude in the inner parts of Disko Fjord. No clear end moraines connected with the lateral formations can be traced, but thick drift near the mouth of Mellemfjord, at Narssârssuk on the southern shore and at Kûggssuaq on the northern shore, may form remnants of an end moraine. Similar thick drift occurs also on the southern and northern shores of the innermost parts of Kangikerdlak in Disko Fjord and at the mouths of some smaller valleys. 
During and after the retreat of the glaciers from the fjords and the main valleys sea level was higher than at present. The marine limit, as determined on the basis of perched boulders in Disko Fjord, is $85 \mathrm{~m}$ above sea level at Qivitut at the mouth of Kuánerssuit suvdluat and Kangikerdlak and $70 \mathrm{~m}$ above sea level at Ikineq further to the north in Disko Fjord. The marine terraces do not reach these altitudes in any of the fjords. In Nordfjord the terraces are $45 \mathrm{~m}$ above sea level at the head of the fjord and in Mellemfjord about $40 \mathrm{~m}$ above sea level at the mouth of the fjord. In the innermost part of Kuánerssuit suvdluat the highest terraces are $30 \mathrm{~m}$ above sea level. In addition, sloping river terraces occur in many valleys, as in the northern part of Blæsedalen, at the southern shore of Kangikerdlak in Disko Fjord.

Some of the marine terraces contain shells, described by Steenstrup $(1883,1901)$, as do some of the small beach ridges between rock outcrops in the gneiss areas in Disko Fjord. The highest shells are from $\mathbf{4 0} \mathrm{m}$ above sea level at Ikineq in Kuánerssuit suvdluat.

After the formation of the marine sediments in the fjords the glaciers again advanced. Numerous small valley glaciers in all three fjords moved down the slopes, often across lateral formations and over former marine terraces. At Enoks Havn in Mellemfjord, for instance, a young moraine rests on the beach terrace at $40 \mathrm{~m}$. Elsewhere the moraines reach down to the present shore. There are no visible traces of a relative regression of sea level after the formation of these moraines. They form long, dark, till-laden ice-tongues, where in places the ice is still visible at the surface. A chronology of the ice advances in Disko may be established with the help of radiocarbon dating of the shells from the marine deposits.

Pingos occur in the formerly submerged valleys of Stordal in Nordfjord and Kildedalen in Mellemfjord. Some of them are $50 \mathrm{~m}$ in diameter and $10 \mathrm{~m}$ high and have a cover of silty material with stones and boulders. Collapsed pingos have no surrounding ridge. The steep slopes of the fjords have a cover of solifluction material, mostly derived from the local till, and talus-cones consisting of coarse material.

\section{References}

Steenstrup, K. J. V. 1883: Bidrag til Kjendskab til de geognostiske og geografiske Forhold i en Del af Nord-Grønland. Meddr Grønland 4, 173-242.

Steenstrup, K. J. V. 1901: Beretning om en Undersøgelsesrejse til Øen Disko i Sommeren 1898. Meddr Grønland 24, 249-306.

Department of Geology, University of Helsinki, Snellmaninkatu 5 , 00170 Helsinki 17, Finland. 